\title{
SOVIET JEWISH EMIGRATION AT A CROSSROADS
}

\author{
Sidney Heitman \\ Dept. of History, Colorado State University, U.S.A.
}

Soviet Jewish emigration is at a crossroads today. Conditions that have impelled more than three-quarters of a million Jews to leave the USSR during the past 45 years have radically changed in recent months, altering the character and dynamics of the exodus and raising important questions concerning its future. Will the current flight of Jews continue, will it grow, or will new developments in the Soviet successor states and elsewhere slow the exodus or end it altogether? Whichever course is taken, what will its consequences be for the emigrants, the former USSR, and the West?

The events that have led Soviet Jewish emigration to this juncture are well known because they have been widely reported in the press. Their ramifications for the movement are not as well understood, however, because they have not been studied until now. This article examines the changes in recent Soviet Jewish emigration and assesses their implications for the future.

\section{Sovlet EmIgration UntII Now}

The recent changes in Soviet Jewish emigration can be best understood if they are viewed in historical perspective - that is, against the background of the movement's evolution until now. Since the exodus began in 1948 , more than 778,000 Soviet Jews have emigrated to the West - two thirds of them to Israel, nearly onethird to the United States, and the remainder to other countries (see the table). Between 1948 and 1989 the number of emigrants averaged fewer than 10,000 persons annually. As a result of Gorbachev's reforms, however, the level rose to unprecedented heights in 1990 and 1991.

Until 1990, the emigrants' motives for leaving were threefold. Religious and Zionist Jews to wanted to "return" to Israel, while others left to escape persecution and discrimination or to seek freedom and a better life in the West. By 1990, these reasons for leaving began to change. Most religious and

Soviet Jewish Emigration, 1948-1991

$\begin{array}{lccccc}\text { Period } & \begin{array}{l}\text { Number of } \\ \text { Emigrants }\end{array} & \begin{array}{l}\text { Annual } \\ \text { Average }\end{array} & \text { Israel } & \text { U.S. } & \text { Others }^{\mathrm{a}} \\ 1948-89 & 391,000 & 9,300 & 191,900 & 170,800 & 28,300 \\ 1990 & 201,300 & - & 181,800 & 6,500 & 13,000 \\ 1991^{\mathrm{b}} & 186,000 & - & 145,000 & 35,000 & 6,000 \\ \text { Total } & 778,300 & - & 518,700 & 212,300 & 47,300\end{array}$

a Other places include Canada, South Africa, Australia, New Zealand and countries in Europe and South America.

b Figures for 1991 are estimates because precise data were not available at the time of writing in early 1992.

Sources: Israeli Embassy, Washington, D.C.; Israeli Consulate General, New York; Hebrew Immigrant Aid Society (HIAS); and U.S. Department of State.

Zionist Jews had left the Soviet Union, and Gorbachev's reforms ended official antisemitism, introduced democracy and religious freedom, and liberalized emigration. However, his policies also led to political disintegration, economic disarray, ethnic conflict and the rise of grassroots antisemitism.

Seeking to escape the economic and political disorder and fearful that they would be made scapegoats for it, unprecedented numbers of Jews rushed to leave the USSR. Whereas in 1987 only 8,200 Jews had emigrated from the USSR, in 1988 the number rose to 19,400 , in 1989 to 72,500 , and in 1990 and 1991 to 201,300 and 186,000 , respectively. Because in 1989 the United States had set a quota on immigration from the USSR of 50,000 persons annually, the vast majority of 1990 and 1991 emigrants went to Israel, where they could resettle without limit (see the table).

\section{Current Sovlet Jewlsh Emigration}

Today Soviet Jews are in an unprecedented position of being able to choose whether to leave the former USSR or to stay and take advantage of the new reforms. Both choices have attractions but also shortcomings. What they decide to do will depend upon the outcome of two contending sets of forces. One set of forces impelling them to leave includes the threat of economic collapse, deepening political disintegration and growing antisemitism. They also fear that there may be a return of repressive authoritarian regimes or that access to Israel may somehow be restricted.

Many observers see only these negative forces and predict a massive exodus in the near future of virtually the entire Soviet Jewish population. What they overlook or minimize, however, is the fact that there are also 
other powerful forces encouraging Soviet Jews to remain in their homeland. These include optimism about the future because of the recent democratic reforms, a revival of Jewish religion, culture, and community life, ${ }^{1}$ and the public condemnation by several leading political figures of past persecution of Jews and assurances of a secure place for them in the new successor states. There is also much resistance to leaving the former USSR because of a strong attachment Soviet Jews have to their homeland, the difficulty of parting with friends and relatives, and a reluctance to pull up roots, leave satisfying positions and accustomed life styles, and undertake the hardships of starting anew in foreign places. Moreover, they are now able to travel abroad freely, making it unnecessary to emigrate in order to avail themselves of opportunities in the West.

Finally, there is mounting concern over the severe shortages of housing and suitable jobs in Israel and the growing tensions in the Middle East. Many Jews who have already emigrated are today urging friends and relatives in the former Soviet Union to postpone leaving or forgo it altogether because of daunting problems for new immigrants to the Jewish state which the Israeli government appears to be unable or unwilling to resolve, and there has even been a small return flow of disillusioned emigrants back to their places of origin.

One result of the conflict between these two sets of forces is that although 1990 and 1991 were record high years of Soviet Jewish emigration, the number of emigrants fell far short of the 400,000 to 500,000 persons annually the Israeli government had hoped for, setting back its plan to resettle one million Soviet immigrants by 1995 . The reason for the shortfall was that many individuals who could have left chose not to do so. According to Israeli authorities Soviet Jews today hold 200,000 entry visas and one million invitations to move to the Jewish state, meaning that virtually the entire Jewish population reported by the 1989 Soviet census (1.4 million persons) could emigrate if they chose to. ${ }^{2}$ Most of them, however, are reportedly "sitting on their suitcases," in the words of one observer, awaiting the outcome of developments at home, in Israel, and in the West before deciding what to do.

\section{Prospects for the future}

Thus, contrary to a widespread belief that the vast majority of Soviet Jews urgently want to leave the former USSR and will do so soon, the fact is that they have viable options today. They can choose to vacate the former USSR en masse, which would mean the end of the historic Jewish presence there; remain and accommodate themselves to the emerging social and political order, which would put an end to mass Jewish emigration; or find a compromise between the two. Judging by the recent past, the course they will take will depend mainly upon future developments in the former Soviet Union and Israel.

If conditions in the successor states worsen, most Jews will undoubtedly emigrate to Israel, regardless of the problems there (unless the United States or other Western countries liberalize their immigration policies, which is highly unlikely). If, however, circumstances improve in the former USSR or deteriorate in the Jewish state, many if not most Soviet Jews may decide to remain where they are indefinitely.

These are only surmises, of course, for there is no reliable information concerning the intentions of hundreds of thousands of diverse and physically dispersed individuals with many generational, occupational and philosophical differences. What is certain is that the course they choose will have profound consequences for them, for Israel and for the West. If most Soviet Jews remain in the former USSR and rebuild their religious and cultural life there, it will mark the start of a new historic era in the annals of Soviet Jewry. If most of them move to Israel, however, it will profoundly alter Israeli society, culture, and politics.

Thus, Soviet Jewish emigration stands at a historic crossroads today from which two or three divergent paths lead out. Which one will be followed cannot be known, but whichever it is will have momentous import for the future.

\section{Notes}

1. According to the Va'ad, the Soviet Jewish umbrella group, there are more than 350 Jewish religious, cultural, educational, and social organizations and scores of new or restored synagogues and temples in the Soviet successor states today, with the number reportedly growing rapidly.

2. Estimates of the "actual" number of Soviet Jews range as high as three million persons, depending upon how Jewish identity is defined and who is doing the estimating. Soviet census figures reflect only selfreported ethnic identification, but many Jews, like members of other disadvantaged Soviet minorities, obscure their nationality or are uncertain of it because of assimilation and intermarriage.

\section{Sourcer}

Sidney Heitman, "Jews in the 1989 USSR Census," Soviet Jewish Affairs, 20, 1, 1990;

- "The New Soviet Emigration Law: A Balance Sheet," Analysis (Institute of Jewish Affairs) 5, July 1991;

- "A Soviet Draft Law on Emigration," Soviet Jewish Affairs, 19, 3, 1989;

— "Soviet Emigration in 1990: A New 'Fourth Wave'?" ibid., 21, 3, 1991;

- "Soviet Emigration Under Gorbachev," ibid., 19, 2, 1989;

- "The Third Soviet Emigration," Soviet Jewish Affairs, 18, 2, 1988;

- Soviet Refugee Monitor, 1, 1, November 1991.

This article is also based on reports in The New York Times, Washington Post, Jerusalem Post and Forward.

(Continued on page 14) 